\title{
Effect of Cultivation on the Soil Properties of El-Kharga Farm, New Valley, Egypt
}

\author{
Gameh, M.A.; Nadia M.K. Roshdy; M.A. Eissa and M.M. Ahmed \\ Soils \& Water Dept. Faculty of Agriculture, Assiut Univ., Egypt
}

Received on: 15/11/2016

Accepted for publication on: 28/12/2016

\begin{abstract}
Assiut University Farm, in El-Kharga Oasis, New Valley Governorate, is located in the Western Desert of Egypt between latitudes $25^{\circ} 30$ - and $25^{\circ} 31-\mathrm{N}$ and longitudes $30^{\circ} 35-$ and $30^{\circ} 36$ - E. This farm was initiated in 2004 to be as experimental farm for the proposed New Valley Branch. Another area is added to the farm in 2014. The location of the farm is in El-Kharga depression which is filled with marine sediments covered with sand sheets. Cultivation of this area for ten years showed great changes in the soil properties. This study aimed to evaluate the capability and suitability of the new area before cultivation and the old cultivated area and to investigate the effect of cultivation on physical and chemical properties of the studied soils.

The results showed that Land Capability for irrigation of the new area was; $30 \%$ Marginally suitable, 43\% Currently not suitable, 26\% Permanently not suitable, while for the old cultivated area was; $11 \%$ Moderately suitable, 27\% Marginally suitable, $27 \%$ Currently not suitable, 33\% Permanently not suitable. With good water quality, the moderately and marginally suitable soils could be improved for agriculture production. The high soil salinity and alkalinity as ESP or SAR also the sandy texture reduced the capability. Correcting those factors will improve the land capability.
\end{abstract}

\section{Keywords: soil properties -El-Kharga-New Vally}

\section{Introduction}

As a result of population increase in Egypt and the urgent need for food, it is necessary to maximize the utilization of natural resources for agriculture production, utilizes land evaluation and its suitability for crop cultivation is the first step to utilize land resources.

One of the important zones for agricultural expansion is the New Valley governorate. The New Valley is the largest governorate in Egypt, it occupies the southern half of the western desert of Egypt, covering an area of $458,000 \mathrm{Km}^{2}$, or about $48 \%$ of the total surface area of Egypt. Assiut University initiated experimental farm in El-Kharga Oasis, to be as experimental farm for the proposed New Valley University branch. Recently another area is being added to the farm. El-Kharga oasis is depression which is filled with marine shale sediments covered with sand sheets. Cultivation of land for ten years showed great changes in soil properties.

The climatological data of ELkharga showed that mean annual temperature is $25-.42^{\circ} \mathrm{C}$ with great difference between summer and winter. The temperature during summer ranges between $22.69^{\circ} \mathrm{C}$ and $41.21^{\circ} \mathrm{C}$, while in winter it varies between $7.52^{\circ} \mathrm{C}$ and $25.17^{\circ} \mathrm{C}$. The low- 
est wind velocities recorded at ELkharga in January was $7.87 \mathrm{~km} / \mathrm{hr}$, and highest velocities recorded was in June $12.54 \mathrm{~km} / \mathrm{hr}$, the annual mean of surface wind velocity was 10.51 $\mathrm{km} / \mathrm{hr}$. The prevailing wind in Elkharga is from north and north west. This wind cause harmful sand movement in the depression.

The relative humidity has a monthly mean value of $24.97 \%$ recorded in June, and $49.79 \%$ recorded in December and; the mean annual humidity in El-kharga Oasis is 35.26 $\%$. The climatological data show that the dryness is prevailing most of the year and there are no wet periods, consequently it may be concluded that the climate of the area is extremely arid. According to the Soil Survey Staff (1999) the climate of the studied area falls into hypothermic temperature regime and torric moisture regime.

The groundwater considered the sole source for water in EL-kharga Oasis for all purposes. The Quaternary aquifer is only found in north ElKharga depression. It is used from Ginah village to northward, where most of farmers drill hand dug wells. The Quaternary aquifer acts as a store for the drain water from the excess irrigation water. Taref Nubian sandstone aquifer is the only water resource used in the south from Ginah village until Gazair village, south of El-Kharga city (Ghoubachi and Baraka, 2006). According to ElBarkouky; (1979) the total dissolved salts in the groundwater samples vary from 810 to $1300 \mathrm{mg} / \mathrm{L}$ and the water quality is good for domestic and agricultural purposes.
Most soils of the area have been possibly formed during the past geological periods while characterized by wet climate, the late tertiary and early Quaternary. The climatic conditions during these periods have acted upon different kinds of parent materials, most important of which are;

- The alluvial deposits of the old terraces.

- The clay shale deposits.

- The sandstone that classified as the Nubian formation.

- The limestone rocks of the Eocene, Miocene and cretaceous ages.

The soils have mostly red and gray color and characterized by weak diagnostic horizons and shallow profiles, the color is mostly that of the parent material, one of the main characteristic is the presence of a vesicular A-horizon. In El-kharga Oasis area, the soils are either deep clay or deep sand; the deep clayey soils represent the old lacustrine deposits, which were laid out during the old geological wet periods in kharga and Beris, and those belonging to the Nubian sandstone mainly in Ginah and Boulaq. Soil textural variations and admixtures of sand with clay material are noticed this could possibly suggest that depressions were laid down under fluviatile Aeolian condition.

The objectives of this work are to study the changes in physical and chemical soils properties of the cultivated old area as compared to the new uncultivated area on.

\section{Materials and Methods}

El-Kharga Oasis lies in the southeast of the Western Desert of Egypt. It covers an area of about $4500 \mathrm{~km}^{2}$. It is located at $140 \mathrm{~km}^{2}$ to the east of El-Dakhla Oasis and 220 
$\mathrm{km}^{2}$ south of Assiut city. It is bounded by longitudes $30^{\circ} 27^{\prime}$ and $30^{\circ} 47^{\prime} \mathrm{E}$ and latitudes $24^{\circ} 30^{\prime}$ and $26^{\circ} 00^{\prime} \mathrm{N}$. The experimental farm of Assiut University, at EL-kharga Oasis occupies two locations: the first (new uncultivated location) of about 136 feddans and the second (old cultivated location) is about 126 feddans.

\section{Field studies and soil sampling}

Sixty seven profiles were sampled to represent the study area (figure 1). Forty six profiles were chosen to represent the uncultivated (first location), (figure 2). and eighteen profiles were chosen to represent the cultivated (second location), (figure 3). Total of 167 Soil samples were collected from the profile layers, according to vertical morphological variations. The soil samples were airdried, crushed and sieved through a 2 $\mathrm{mm}$ sieve and stored in plastic containers for physical, chemical analyses.

\section{Physical and Chemical Analytical Methods}

-Mechanical analysis was determined by the pipette method (Baver, 1963). Total carbonates were removed by sodium acetate, buffered at $\mathrm{pH} 5.0$, as described by Jackson (1969).

-Soil Color: Color of soil samples was determined in both wet and dry samples using Munsell Color Charts, USDA, Soil Survey Staff (1951).

-Soil bulk density of soil samples was determined by the graduated cylinder method (Bodman, 1946), since the samples were friable sand.

-Soil particle density was determined by the pycnometer method (Blake and Hartge, 1986).
-Hydraulic Conductivity Coefficient was determined using undisturbed soil cores, using Darcy law (Richards, 1954).

-Porosity Total porosity was calculated using the real and apparent densities (Richards, 1954).

-Soil $\mathrm{pH}$ was measured by $\mathrm{pH}$ meter in 1: 2.5 (Soil: Water) suspension .

-Calcium Carbonate content was measured by Calcimeter.

-Soil paste extract: extract was prepared for each soil sample as 1:1 (soil: water.)

-The electrical conductivity of the soil paste extract (ECe) was calculated using electrical conductivity meter of 1:1 (soil: water extracts).

- Soluble cations: sodium and potassium were measured by flame photometer, while calcium and magnesium were determined volumetrically by EDTA titration method.

-Soluble anions: chlorides were titrated by of silver nitrate solution. Sulphates were measured using the turbidometeric method. Carbonates and bicarbonates were titrated by a standard solution of hydrochloric acid.

-Available phosphorus was extracted by $(0.5 \mathrm{M}) \mathrm{NaHCO}_{3}$ at $\mathrm{pH} 8.5$ (Olsen et al., 1954) then measured calorimetrically.

-Available potassium was extracted by $(1 \mathrm{~N}) \mathrm{NH}_{4} \mathrm{OAC}$ at $\mathrm{pH} 7.0$

- Cation Exchange Capacity (CEC) was measured by using (1 M) sodium acetate and replaced by $\mathrm{NH}_{4}{ }^{+}$ then sodium was measured by flame photometer

-Exchangeable sodium percentage (ESP) 
-Sodium Adsorption Ratio (SAR) was calculated.

All the above tests were conducted according to Jackson, 1967 and 1973 except the referenced tests.
-Gypsum was measured by the acetone method (Nelson, 1982).

-Arc- GIS computer program was used to draw the map of the obtained data.

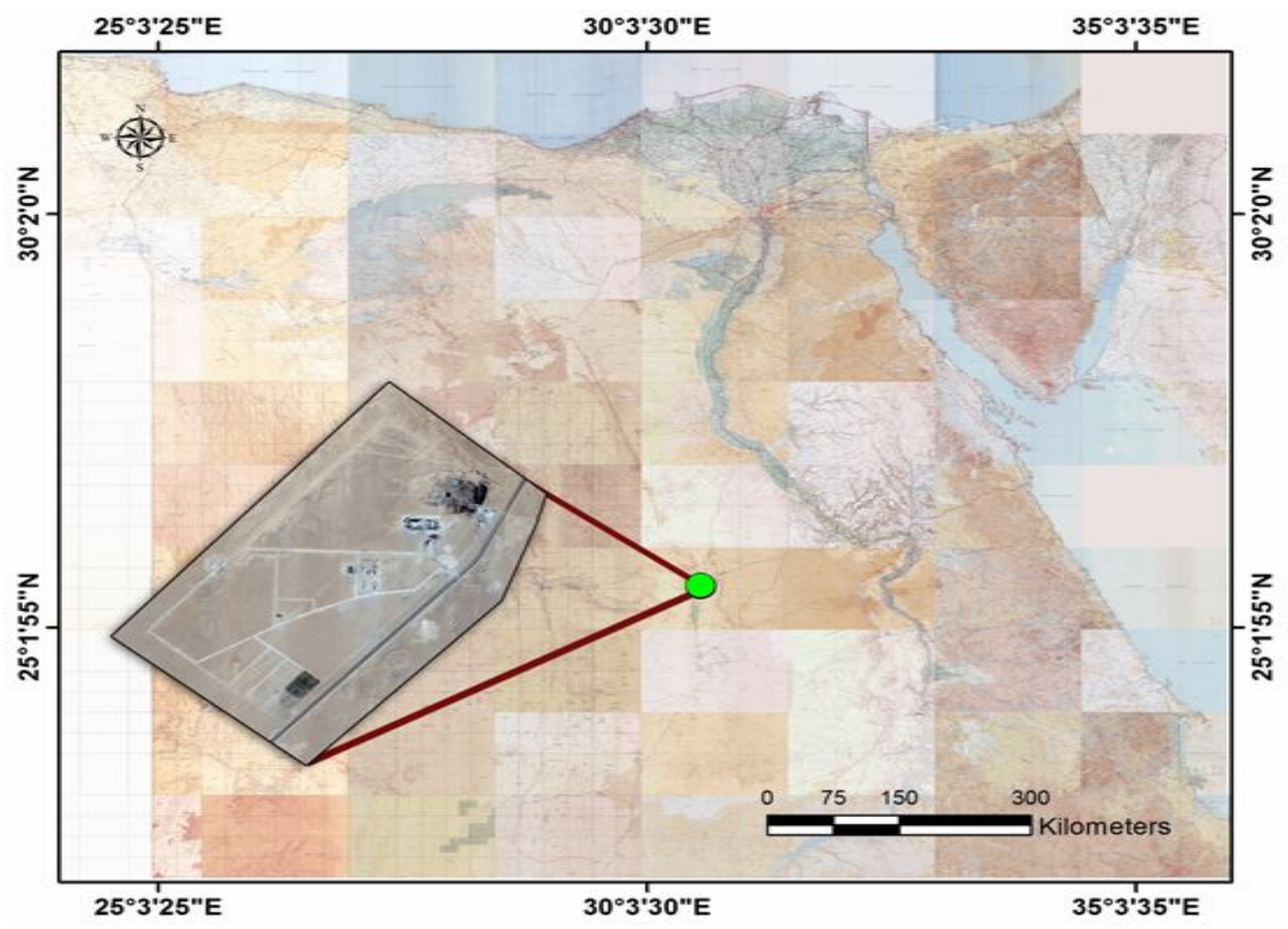

Fig. 1: Map of Egypt, showing university farm, at El-Kharga Oasis.

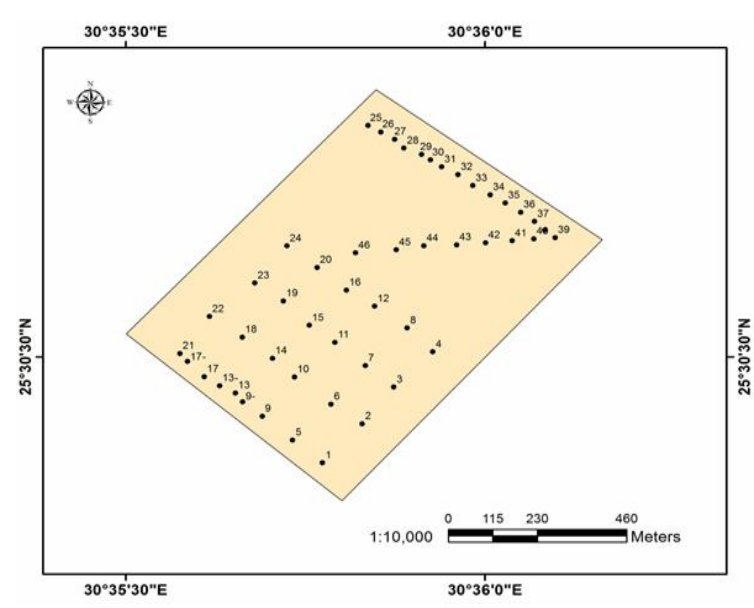

Fig.2: Map shows the new uncultivated location (first location)

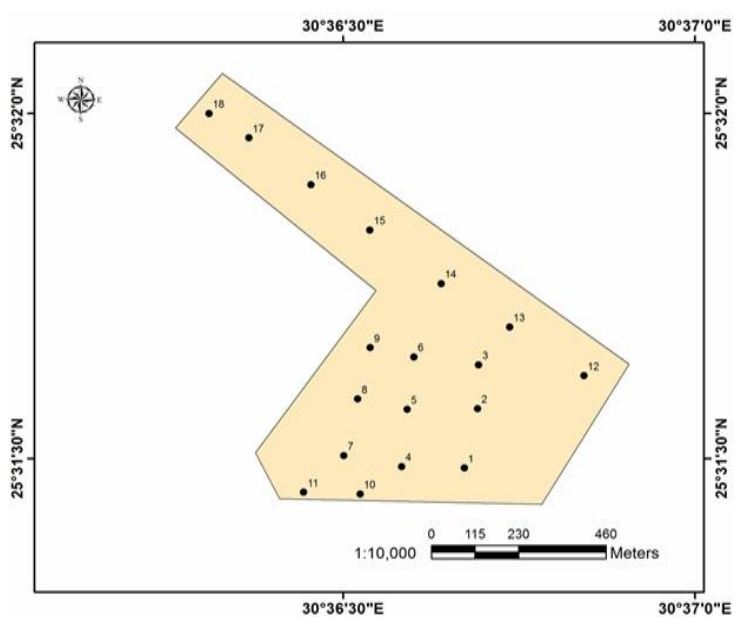

Fig.3: Map shows the old cultivated location (second location) 
-Land capability using Sys and Verheye (1972) criteria:

Quantitative estimation of soil characteristics i.e., slope, drainage conditions (wetness), soil depth, texture, carbonate content, gypsum status, and salinity were used for evaluation. Capability indexes for irrigation were calculated according to Sys and Verheye (1972). The land capability index (Ci) for irrigation was calculated by the following equation:

$$
C i=A \times B / 100 \times C / 100 \times D / 100 \times E / 100 \times F / 100 \times G / 100
$$

Where:

Ci: Capability index
A: Texture
B: Soil depth
C: Carbonate status
D: Gypsum status
E: Salinity
F: Drainage conditions
G: Slope

The rating of limiting factors and the category level according to Sys and Verheye (1972).

Table 1. Soil grade and rating values according to Sys and Verheye (1972).

\begin{tabular}{|c|c|c|}
\hline Soil grade & Class & Ci \\
\hline Highly suitable & I & $>80 \%$ \\
\hline Moderately suitable & II & $60-80 \%$ \\
\hline Marginally suitable & III & $45-60 \%$ \\
\hline Almost unsuitable & IV & $30-45 \%$ \\
\hline Unsuitable & V & $20-30 \%$ \\
\hline Completely unsuitable & VI & $<20 \%$ \\
\hline
\end{tabular}

\section{Results and Discussion}

\section{1-Particle-size distribution:}

Particle size distribution of soil samples of the new uncultivated location and old cultivated location understudy were illustrated in figure 4: $\mathrm{a}-\mathrm{b}$, and in Tables $2 \& 3$.

The soils of the new uncultivated location are mainly coarse in texture $(42.85 \%$ loamy sand, 32.65 $\%$ sandy loam, $22.44 \%$ sand. (These coarse textures reflect the effect of the sandy wind plowing from the north passing by the sand dunes line of Abo-Mohreek in the western desert. The old cultivated location soils were mostly fine to medium coarse in texture (44.44 \% loamy sand, followed by $33.33 \%$ sandy loam, fig.2$\mathrm{b}$ and Table 2). Only profiles 2, 17, 18 , and 13 were clay, clay loam, loam, and sandy clay loam, respectively. Which represented $22.23 \%$ of the area can be due to the naturally alluvial deposits which were added from the surrounding areas. 


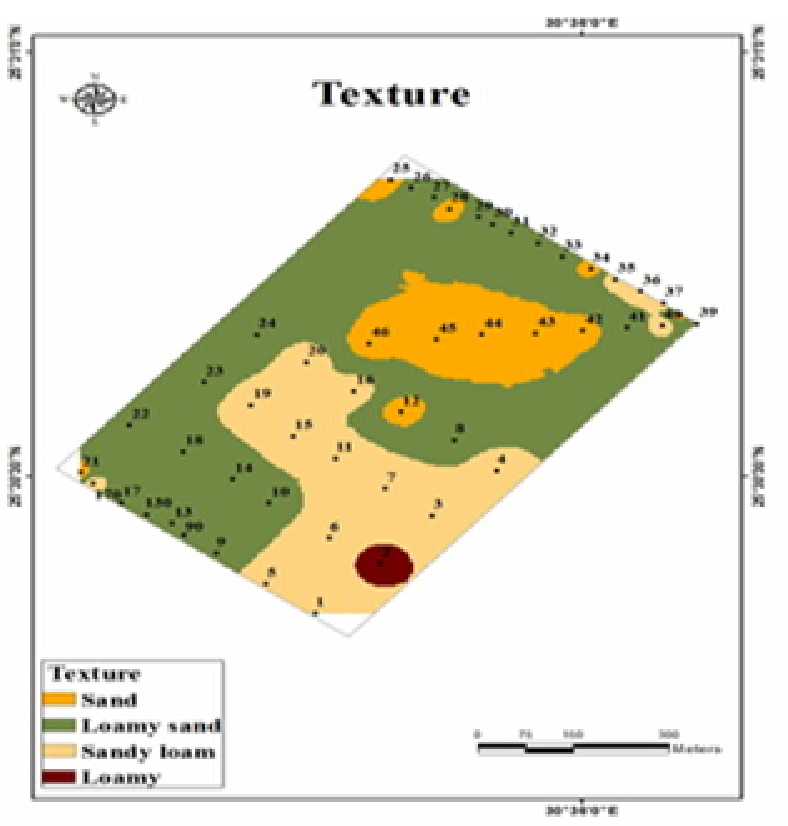

(a) New uncultivated location

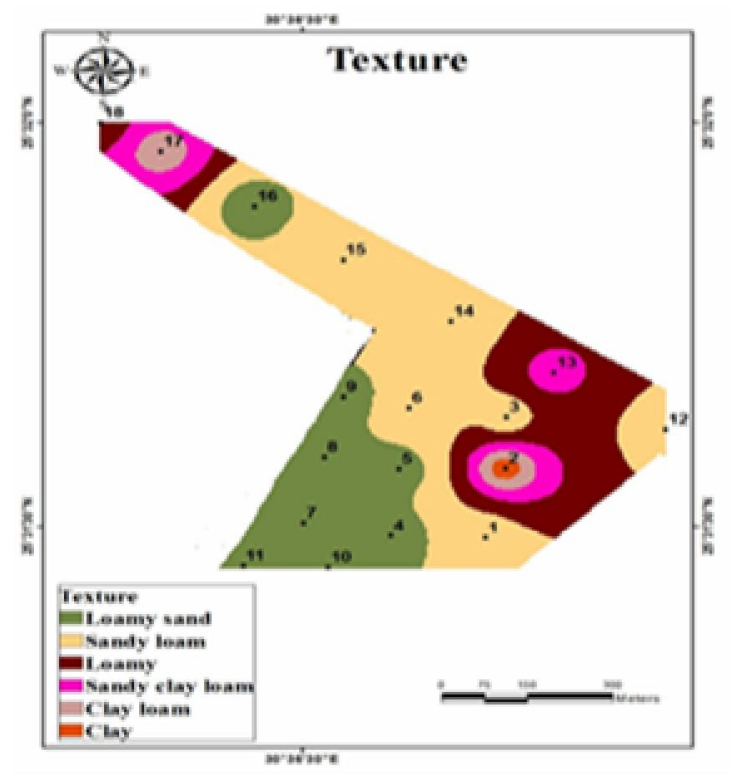

(b) Old cultivated locatio

Fig. 4: The particle-size distribution as average profile values in both locations

Table 2. Physical and chemical properties for the new uncultivated location (first location).

\begin{tabular}{|c|c|c|c|c|c|c|}
\hline \multirow{2}{*}{ Profile No. } & \multirow{2}{*}{$\begin{array}{c}0-120 \\
\text { Depth (em) }\end{array}$} & \multicolumn{3}{|c|}{ P\&q tilcle size gissribution.f\%o) } & \multirow{2}{*}{$\begin{array}{l}\text { Sandy } \\
\text { Soil Texture grade }\end{array}$} & \multirow{2}{*}{ ECé(âs/m) } \\
\hline & & Sand & Silt & Clay & & \\
\hline 1 & $0-150$ & 53.25 & 33.20 & 13.55 & Sandy loam & 40.94 \\
\hline 2 & $0-150$ & 40.45 & 38.40 & 21.15 & Loamy & 175.03 \\
\hline 3 & $0-150$ & 72.05 & 23.33 & 4.62 & Sandy loam & 24.56 \\
\hline 4 & $0-120$ & 60.38 & 29.16 & 10.44 & Sandy loam & 96.31 \\
\hline 5 & $0-150$ & 62.21 & 23.73 & 14.06 & Sandy loam & 39.64 \\
\hline 6 & $0-150$ & 55.60 & 34.26 & 10.14 & Sandy loam & 47.02 \\
\hline 7 & $0-120$ & 58.48 & 30.66 & 10.86 & Sandy loam & 181.40 \\
\hline 8 & $0-120$ & 82.55 & 14.33 & 3.11 & Loamy sand & 36.13 \\
\hline 9 & $0-120$ & 84.58 & 12.13 & 3.28 & Loamy sand & 82.04 \\
\hline $9 *$ & $0-150$ & 80.85 & 14.00 & 4.48 & Loamy sand & 35.83 \\
\hline 10 & $0-150$ & 82.37 & 11.86 & 5.66 & Loamy sand & 22.44 \\
\hline 11 & $0-150$ & 68.13 & 25.86 & 6.00 & Sandy loam & 152.13 \\
\hline 12 & $0-100$ & 89.12 & 8.00 & 2.08 & Sandy & 67.10 \\
\hline 13 & $0-150$ & 77.41 & 17.20 & 5.39 & Loamy sand & 79.14 \\
\hline $13 *$ & $0-150$ & 84.53 & 12.53 & 2.93 & Loamy sand & 47.03 \\
\hline 14 & $0-120$ & 82.32 & 10.66 & 7.01 & Loamy sand & 125.54 \\
\hline 15 & $0-150$ & 60.08 & 22.40 & 17.52 & Sandy loam & 16.39 \\
\hline 16 & $0-150$ & 70.64 & 12.40 & 17.12 & Sandy loam & 37.71 \\
\hline 17 & $0-150$ & 80.05 & 17.06 & 2.88 & Loamy sand & 25.46 \\
\hline $17 *$ & $0-100$ & 75.44 & 15.80 & 8.76 & Sandy loam & 17.27 \\
\hline 18 & $0-150$ & 78.00 & 17.73 & 4.26 & Loamy sand & 19.11 \\
\hline 19 & $0-150$ & 63.89 & 18.26 & 18.90 & Sandy loam & 22.80 \\
\hline 20 & $0-150$ & 66.32 & 22.40 & 11.28 & Sandy loam & 19.51 \\
\hline
\end{tabular}


Table 2. (continued) Physical and chemical properties for the new uncultivated location (first location).

\begin{tabular}{|c|c|c|c|c|c|c|}
\hline Profile & Depth & \multicolumn{2}{|c|}{ Particle size distribution (\%) } & \multirow{2}{*}{ Soil Texture grade } & \multirow{2}{*}{ ECe(dS/m) } \\
\cline { 3 - 5 }$(\mathbf{c m})$ & Sand & Silt & Clay & & \\
\hline 22 & $0-250$ & 83.78 & 12.13 & 4.08 & Loamy sand & 32.45 \\
\hline 23 & $0-30$ & 78.18 & 18.66 & 3.14 & Loamy sand & 8.53 \\
\hline 24 & $0-150$ & 81.28 & 14.40 & 4.48 & Loamy sand & 19.07 \\
\hline 25 & $0-120$ & 87.25 & 10.66 & 2.08 & Sandy & 55.38 \\
\hline 26 & $0-110$ & 85.06 & 7.75 & 7.18 & Loamy sand & 108.80 \\
\hline 27 & $0-120$ & 86.56 & 7.14 & 6.29 & Loamy sand & 83.63 \\
\hline 28 & $0-120$ & 87.66 & 7.33 & 5.00 & Sandy & 134.47 \\
\hline 29 & $0-110$ & 77.81 & 15.63 & 6.54 & Loamy sand & 84.29 \\
\hline 30 & $0-150$ & 85.80 & 7.80 & 6.40 & Loamy sand & 29.00 \\
\hline 31 & $0-120$ & 84.16 & 10.83 & 5.00 & Loamy sand & 16.81 \\
\hline 32 & $0-150$ & 86.26 & 9.73 & 4.00 & Loamy sand & 13.00 \\
\hline 33 & $0-150$ & 85.76 & 7.93 & 6.30 & Loamy sand & 21.90 \\
\hline 34 & $0-150$ & 88.46 & 7.26 & 4.53 & Sandy & 20.88 \\
\hline 35 & $0-120$ & 77.00 & 15.00 & 8.00 & Sandy loam & 30.23 \\
\hline 36 & $0-120$ & 69.66 & 22.33 & 8.00 & Sandy loam & 64.24 \\
\hline 37 & $0-120$ & 74.50 & 17.16 & 8.33 & Sandy loam & 40.64 \\
\hline 38 & $0-120$ & 87.66 & 7.66 & 4.66 & Sandy & 29.23 \\
\hline 39 & $0-120$ & 82.75 & 8.91 & 8.33 & Loamy sand & 41.21 \\
\hline 40 & $0-120$ & 77.50 & 15.16 & 7.91 & Sandy loam & 158.00 \\
\hline 41 & $0-130$ & 86.30 & 7.00 & 6.69 & Loamy sand & 110.41 \\
\hline 42 & $0-120$ & 87.83 & 7.00 & 5.16 & Sandy & 80.29 \\
\hline 43 & $0-130$ & 87.23 & 6.76 & 6.00 & Sandy & 47.56 \\
\hline 44 & $0-120$ & 88.33 & 7.66 & 4.00 & Sandy & 47.35 \\
\hline 45 & $0-130$ & 86.30 & 7.00 & 6.07 & Sandy & 107.04 \\
\hline 46 & $0-150$ & 87.66 & 6.33 & 6.00 & Sandy & 75.53 \\
\hline First site & & 77.73 & 15.08 & 7.18 & Loamy sand & 58.74 \\
\hline Overall avg. & & 74.77 & 16.63 & 8.60 & Sandy loam & 46.76 \\
\hline
\end{tabular}

Table 3. Physical and chemical properties for the new cultivated location (second location).

\begin{tabular}{|c|c|c|c|c|c|c|}
\hline \multirow{2}{*}{ Profile No. } & \multirow{2}{*}{ Depth (cm) } & \multicolumn{6}{|c|}{ Particle size distribution (\%) } & \multirow{2}{*}{ Soil Texture grade } & \multirow{2}{*}{ ECe(dS/m) } \\
\cline { 3 - 5 } & & Sand & Silt & Clay & & \\
\hline 1 & $0-150$ & 73.12 & 9.93 & 16.94 & Sandy loam & 1.01 \\
\hline 2 & $0-100$ & 32.32 & 20.00 & 47.68 & Clay & 4.92 \\
\hline 3 & $0-100$ & 46.32 & 47.00 & 6.68 & Sandy loam & 10.85 \\
\hline 4 & $0-100$ & 85.12 & 11.30 & 3.58 & Loamy sand & 2.24 \\
\hline 5 & $0-80$ & 87.82 & 4.76 & 7.42 & Loamy sand & 3.04 \\
\hline 6 & $0-100$ & 56.52 & 35.30 & 8.18 & Sandy loam & 10.90 \\
\hline 7 & $0-120$ & 78.15 & 17.33 & 4.52 & Loamy sand & 28.85 \\
\hline 8 & $0-100$ & 84.92 & 12.90 & 2.18 & Loamy sand & 16.39 \\
\hline 9 & $0-100$ & 85.52 & 11.60 & 2.88 & Loamy sand & 27.85 \\
\hline 10 & $0-100$ & 80.72 & 14.00 & 5.28 & Loamy sand & 29.76 \\
\hline 11 & $0-100$ & 85.92 & 11.40 & 2.68 & Loamy sand & 17.85 \\
\hline 12 & $0-150$ & 64.72 & 19.20 & 16.08 & Sandy loam & 11.45 \\
\hline 13 & $0-120$ & 65.32 & 10.08 & 24.60 & Sandy clay loam & 5.19 \\
\hline 14 & $0-150$ & 70.58 & 20.00 & 9.42 & Sandy loam & 18.00 \\
\hline 15 & $0-120$ & 71.65 & 19.33 & 9.01 & Sandy loam & 1.56 \\
\hline 16 & $0-150$ & 80.98 & 15.33 & 3.69 & Loamy sand & 36.86 \\
\hline 17 & $0-150$ & 22.32 & 50.00 & 27.68 & Clay loam & 7.15 \\
\hline 18 & $0-150$ & 28.72 & 45.60 & 25.68 & Loamy & 20.87 \\
\hline Second site & & 66.71 & 20.84 & 12.45 & Sandy loam & 14.15 \\
\hline Overall avg. & & 74.77 & 16.63 & 8.60 & Sandy loam & 46.76 \\
\hline
\end{tabular}




\section{2-Total soluble salts (ECe)}

The electrical conductivity of the saturated soil extracts (ECe) of the studied soil samples is shown in Tables $2 \& 3$. Distribution pattern of soil salinity levels in the studied profiles is illustrated in figure 5: $a-b$, as profile average ECe.

The profile average electrical conductivity (ECe) values of the new uncultivated location (first location) varied between 7.94 and 158.00 $\mathrm{dS} / \mathrm{m}$. Most of soil samples for this location are very strongly saline (Fig ${ }^{-}$-a). The highest ECe profile average values were found in profiles 2, 7 (175.03-181.40 dS/m). Few numbers of profiles have ECe Less than 16 $\mathrm{dS} / \mathrm{m}$ such as profiles 21, 23, 32 . Only $6.21 \%$ of the profiles consider high saline, and $93.87 \%$ are very high saline according to the salinity classification by Richards (1954). However, the ECe of soil samples reached values of $414.30 \mathrm{dS} / \mathrm{m}$ at depth of 10 $30 \mathrm{~cm}$ of profile 2 , and $306.50 \mathrm{ds} / \mathrm{m}$ at the surface and $124.20 \mathrm{dS} / \mathrm{m}$ at the bottom layers. This was not the only case but it was the highest, since ECe values over $50 \mathrm{dS} / \mathrm{m}$ were shown in 57 samples out of 127 which represent $45 \%$ of the samples, also $21 \%$ of these samples have ECe> 100 $\mathrm{dS} / \mathrm{m}$ and $6.3 \%$ of those samples have ECe more than $200 \mathrm{dS} / \mathrm{m}$.

The field observations showed salt layers of $\mathrm{NaCl}$ at depths varied from 20 to $50 \mathrm{~cm}$ in profile 1 , and from 0 to $150 \mathrm{~cm}$ in profile 2 . These salty layers were associated with dark brownish soil color which was suspected to be shales. This dark brownish layer is extended in all the study area but at variable depths starting from $10 \mathrm{~cm}$ to $150 \mathrm{~cm}$. The salt layers usually appeared on the border line between the sandy sheet on the top surface layer and the brownish layer as the second layer it was shown as clear crystals of $\mathrm{NaCl}$. However, in some location the salt was white niddle crystals of gypsum insertedin the dark brown or the green or gray shales. The area seems to be as basin of old sea which dried and deposited shales and $\mathrm{NaCl}, \mathrm{SO}_{4}{ }^{-2}$ this proposed basin in drawn in Figure-5 to represent the shales layer which is excepted to be as hard bane and would cause submerged and will be soon filed with irrigation water and cause salinity and sodicity in near future.

Back to Table 2 to compare the texture of the samples and correlate it with the ECe, it will be shown clearly that the high ECe layer usually is above or in loamy or sandy loam or clay loam texture.

For the old cultivated location the ECe range between 1.01 and $36.86 \mathrm{dS} / \mathrm{m}$, the data show that 11.11 $\%$ were very low ECe, $11.11 \%$ were low, $16.66 \%$ were medium, $16.66 \%$ were high, and $44.44 \%$ were very high saline according to the salinity classification by Richards (1954), except some profiles such as $7,8,9,10$, $11,14,16$ and 18 are very strongly saline $(>16 \mathrm{dS} / \mathrm{m})$. The lowest values of ECe were found in some soil samples of profiles 1and 15 (1.01-1.56 $\mathrm{dS} / \mathrm{m})$.

Generally, the high content of soluble salts, especially in the surface layers of most profiles of the new uncultivated location (first location), could be attributed to the absence of any leaching due to the scanty rainfall received and the barren nature of the 
soils. On other hand, lower salinity levels in the old cultivated location (second location) compared to the first one (new uncultivated location) that may possibly due to the effect of irrigation water and agricultural activities practiced in this location. It is noticeable that the surface layer had higher ECe than the subsurface layers which may be due to the deposits which maintain salts upward movement of the salts with the hyper arid weather in El-Kharga. That was shown in profiles $7,8,9,10,11,14$, and 16.

Profile14 have ECe of 126.61 $\mathrm{dS} / \mathrm{m}$ at the surface, while the next layer at $20 \mathrm{~cm}$ depth have ECe of only $27.62 \mathrm{dS} / \mathrm{m}$ both layers have sandy loam texture. In that profile the upward movement of salts may be the cause. Profile 16 had irregular ECe of layers 2, 3, 4 and 5 since the ECe were $242.07,16.97,75.29$, and 19.04 $\mathrm{dS} / \mathrm{m}$, respectively. The texture of the respective layers were sandy loam (39.68 \% fine fraction), sandy (11.68 $\%$ fine fraction), sandy loam $37.68 \%$ fine fraction), and sandy (11.68\% fine fraction). The fine fraction associated well with the salinity level. This fine fraction is manly shales, which is marine sediments.

The average ECe of the uncultivated area was $58.74 \mathrm{dS} / \mathrm{m}$, while that of the cultivated area was 14.15 $\mathrm{dS} / \mathrm{m}$. However, the whole studied soil samples (167 samples and 67 profiles) average was $46.76 \mathrm{dS} / \mathrm{m}$.

This study revealed that salinity would be the worst problem facing cultivation of this area either the new or the old site. Recently digging to 4 meters in the old cultivated site revealed very highly saline drainage water at depth of 3-4 meters which under lined by shales layer which consider the base of dish will be field by saline drainage water and deteriorate the soil. Building drainage system is very necessary to continue cultivation of this farm.

These results agree with those of obtained by (Salama, 1965, Harga, 1977, Harga, 1979, El-Hamdi 1990, Hammad and Hussein, 1993, AbdAallah, 2002, Selmy 2005). 

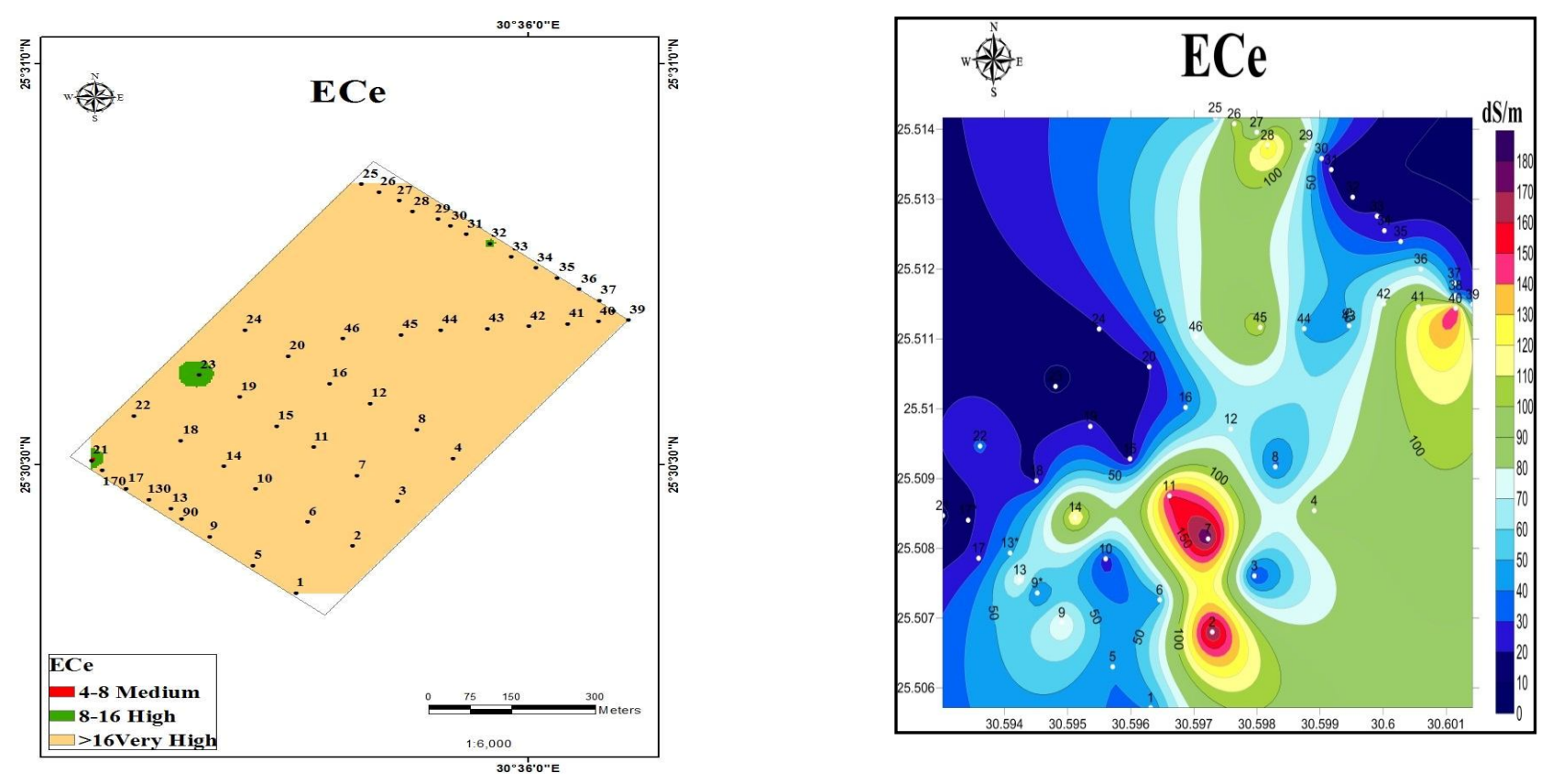

(a) New uncultivated location
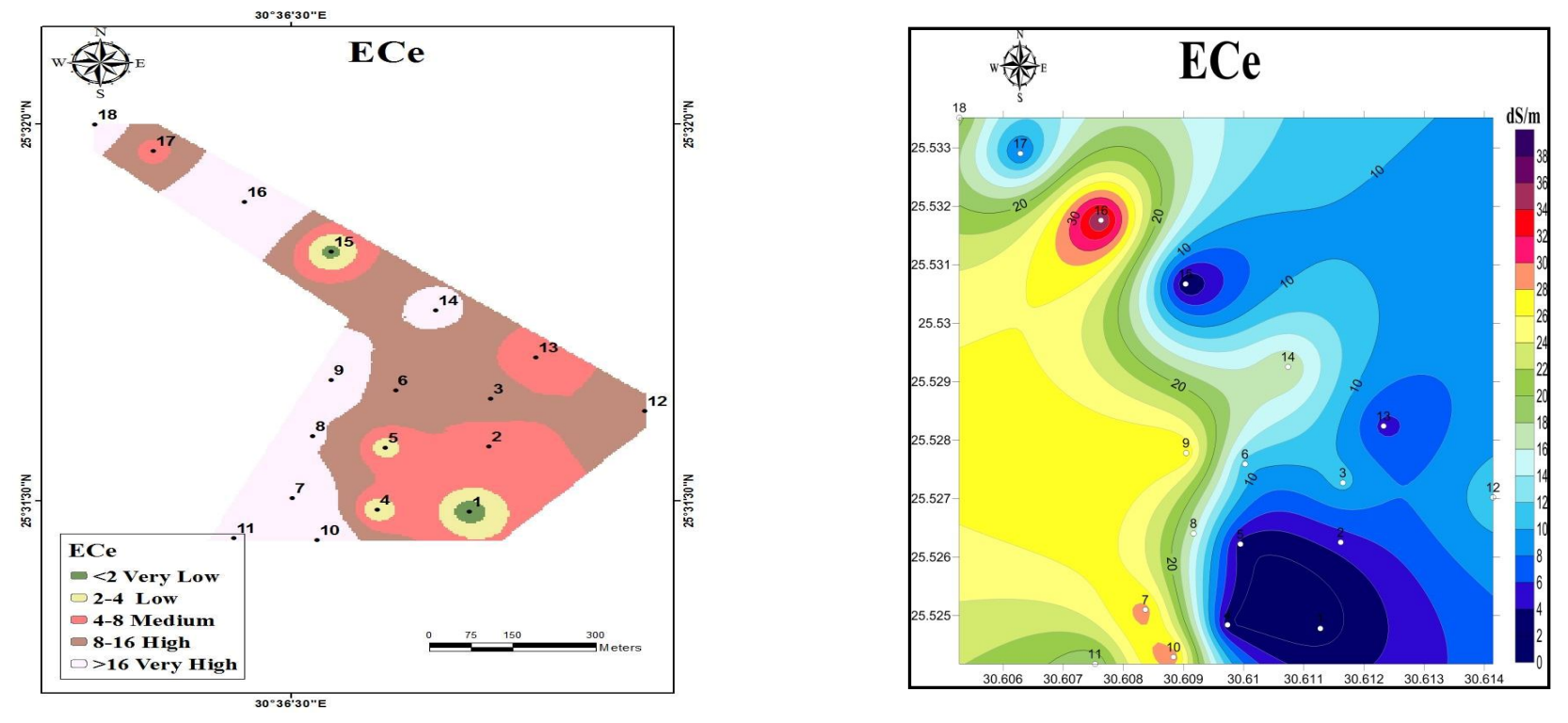

(b) Old cultivated location

Fig.5 (a-b): The distribution of salinity (ECe as $\mathrm{dS} / \mathrm{m}$ ) as average profiles value in both locations. 


\section{3 -Land capability evaluation}

The estimated rating and calculated soil index of the studied soil profiles are shown in (Tables 4,5$)$ as illustrated in figure 6 : $a-b$, for both locations.

The results of new uncultivated location (first location), showed that most of soils are unsuitable to marginally suitable; as their rates values (Ci) range between 20.52-57.00\%. Few profiles were completely unsuitable such as 12,25,28, and 46 which have $\mathrm{Ci}$ values of $15.83,19.95,18.52$, and $19.95 \%$, respectively.

Also the old cultivated location (second location) was mostly unsuitable to marginally suitable; as their rates values $(\mathrm{Ci})$ range between 23.70-54.15\%, except some profiles were moderately suitable such as in profiles 15 and 1 of 60.91 and 67.68 $\%$, respectively.

Generally, land capability for irrigation of the new uncultivated loca- tion (first location) was; $28.57 \%$ of the profiles were marginally suitable (III), $46.93 \%$ were almost unsuitable (IV), $16.32 \%$ were unsuitable (V), $8.16 \%$ were completely unsuitable (VI). While, land capability for the old cultivated location (second location) was; $11.11 \%$ of the profiles were moderately suitable (II), 27.77 $\%$ were marginally suitable (III), $27.77 \%$ were almost unsuitable (IV), and $33.33 \%$ were unsuitable (V).

Most profiles for the new uncultivated location (first location), and the old cultivated location (second location) are considered unsuitable to marginally suitable for irrigation, under good conditions of water availability for agricultural purposes; the moderately and marginally suitable soils for irrigation could be safely used in agriculture. 
Table 4. Land capability indexes for irrigation of the new uncultivated location (first location), as calculated according to Sys and Verheye (1972). $\mathrm{Ci}=\mathrm{A} \times \mathrm{B} / 100 \times \mathrm{C} / 100 \times \mathrm{D} / 100 \times \mathrm{E} / 100 \times \mathrm{F} / 100 \times \mathrm{G} / 100$

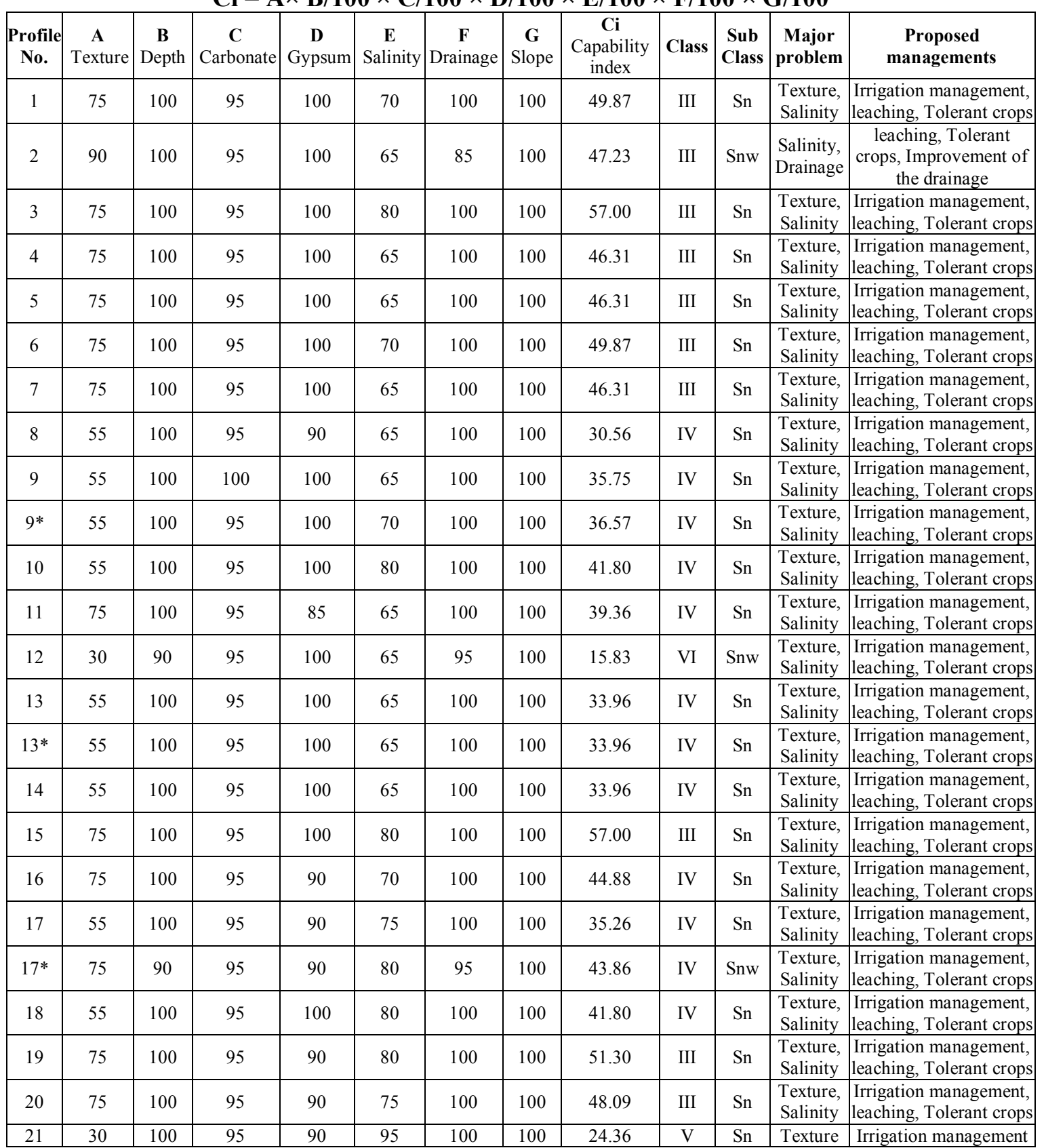

$(\mathbf{S}=\mathrm{A}, \mathrm{B}, \mathrm{C}, \mathrm{D})(\mathbf{n}=\mathrm{E})(\mathbf{W}=\mathrm{F}),(\mathrm{III}=$ Marginally suitable, 45-60\%), (IV= Almost unsuitable, 30-45\%), (V= Unsuitable, $20-30 \%),(\mathrm{VI}=$ Completely unsuitable, $<20 \%)$ 
Table 4. (Continued) Land capability indexes for irrigation of the new uncultivated location (first location), as calculated according to Sys and Verheye (1972). $\mathrm{Ci}=\mathrm{A} \times \mathrm{B} / \mathbf{1 0 0} \times \mathrm{C} / \mathbf{1 0 0} \times \mathrm{D} / \mathbf{1 0 0} \times \mathrm{E} / \mathbf{1 0 0} \times \mathrm{F} / \mathbf{1 0 0} \times \mathrm{G} / \mathbf{1 0 0}$

\begin{tabular}{|c|c|c|c|c|c|c|c|c|c|c|c|c|}
\hline $\begin{array}{l}\text { Profile } \\
\text { No. }\end{array}$ & $\begin{array}{l}\text { A } \\
\text { Tex- } \\
\text { ture } \\
\end{array}$ & $\begin{array}{c}\text { B } \\
\text { Depth }\end{array}$ & $\begin{array}{c}\mathbf{C} \\
\text { Carbonate }\end{array}$ & $\begin{array}{c}\text { D } \\
\text { Gypsum }\end{array}$ & $\underset{\text { Salinity }}{\mathbf{E}}$ & $\begin{array}{c}\mathbf{F} \\
\text { Drainage }\end{array}$ & $\begin{array}{c}\mathbf{G} \\
\text { Slope }\end{array}$ & \begin{tabular}{|c|}
$\mathbf{C i}$ \\
Capability \\
index
\end{tabular} & Class & $\begin{array}{c}\text { Sub } \\
\text { Class }\end{array}$ & $\begin{array}{c}\text { Major } \\
\text { problem }\end{array}$ & $\begin{array}{l}\text { Proposed manage- } \\
\text { ments }\end{array}$ \\
\hline 22 & 55 & 100 & 95 & 90 & 70 & 100 & 100 & 32.91 & IV & $\mathrm{Sn}$ & $\begin{array}{l}\text { Texture, } \\
\text { Salinity }\end{array}$ & $\begin{array}{c}\text { Irrigation management, } \\
\text { leaching, Tolerant } \\
\text { crops }\end{array}$ \\
\hline 23 & 55 & 60 & 95 & 90 & 90 & 95 & 100 & 24.12 & V & Snw & $\begin{array}{c}\text { Texture, } \\
\text { Depth }\end{array}$ & $\begin{array}{c}\text { Irrigation management, } \\
\text { deep plowing }\end{array}$ \\
\hline 24 & 55 & 100 & 95 & 90 & 80 & 100 & 100 & 37.62 & IV & $\mathrm{Sn}$ & \begin{tabular}{l|} 
Texture, \\
Salinity
\end{tabular} & $\begin{array}{c}\text { Irrigation management, } \\
\text { leaching, Tolerant } \\
\text { crops }\end{array}$ \\
\hline 25 & 30 & 100 & 95 & 100 & 70 & 100 & 100 & 19.95 & VI & $\mathrm{Sn}$ & $\begin{array}{l}\text { Texture, } \\
\text { Salinity }\end{array}$ & $\begin{array}{c}\text { Irrigation management, } \\
\text { leaching, Tolerant } \\
\text { crops }\end{array}$ \\
\hline 26 & 55 & 100 & 95 & 100 & 75 & 100 & 100 & 39.18 & IV & $\mathrm{Sn}$ & $\begin{array}{l}\text { Texture, } \\
\text { Salinity }\end{array}$ & \begin{tabular}{|c|} 
Irrigation management, \\
leaching, Tolerant \\
crops
\end{tabular} \\
\hline 27 & 55 & 100 & 95 & 100 & 75 & 100 & 100 & 39.18 & IV & $\mathrm{Sn}$ & $\begin{array}{l}\text { Texture, } \\
\text { Salinity }\end{array}$ & $\begin{array}{c}\text { Irrigation management, } \\
\text { leaching, Tolerant } \\
\text { crops }\end{array}$ \\
\hline 28 & 30 & 100 & 95 & 100 & 65 & 100 & 100 & 18.52 & VI & $\mathrm{Sn}$ & $\begin{array}{l}\text { Texture, } \\
\text { Salinity }\end{array}$ & $\begin{array}{c}\text { Irrigation management, } \\
\text { leaching, Tolerant } \\
\text { crops }\end{array}$ \\
\hline 29 & 55 & 100 & 95 & 90 & 65 & 100 & 100 & 30.56 & IV & $\mathrm{Sn}$ & $\begin{array}{l}\text { Texture, } \\
\text { Salinity }\end{array}$ & $\begin{array}{c}\text { Irrigation management, } \\
\text { leaching, Tolerant } \\
\text { crops }\end{array}$ \\
\hline 30 & 55 & 100 & 95 & 90 & 80 & 100 & 100 & 37.62 & IV & $\mathrm{Sn}$ & $\begin{array}{l}\text { Texture, } \\
\text { Salinity }\end{array}$ & $\begin{array}{c}\text { Irrigation management, } \\
\text { leaching, Tolerant } \\
\text { crops }\end{array}$ \\
\hline 31 & 55 & 100 & 100 & 90 & 85 & 100 & 100 & 42.07 & IV & $\mathrm{Sn}$ & Texture & Irrigation management \\
\hline 32 & 55 & 100 & 95 & 90 & 85 & 100 & 100 & 39.97 & IV & $\mathrm{Sn}$ & Texture & Irrigation management \\
\hline 33 & 55 & 100 & 95 & 100 & 75 & 100 & 100 & 39.18 & IV & $\mathrm{Sn}$ & $\begin{array}{l}\text { Texture, } \\
\text { Salinity }\end{array}$ & $\begin{array}{c}\text { Irrigation management, } \\
\text { leaching, Tolerant } \\
\text { crops }\end{array}$ \\
\hline 34 & 30 & 100 & 95 & 90 & 80 & 100 & 100 & 20.52 & $\mathrm{~V}$ & $\mathrm{Sn}$ & $\begin{array}{l}\text { Texture, } \\
\text { Salinity }\end{array}$ & \begin{tabular}{|c|} 
Irrigation management, \\
leaching, Tolerant \\
crops
\end{tabular} \\
\hline 35 & 75 & 100 & 95 & 90 & 80 & 100 & 100 & 51.30 & III & $\mathrm{Sn}$ & $\begin{array}{l}\text { Texture, } \\
\text { Salinity }\end{array}$ & \begin{tabular}{|c|}
$\begin{array}{c}\text { Irrigation management, } \\
\text { leaching, Tolerant } \\
\text { crops }\end{array}$ \\
\end{tabular} \\
\hline 36 & 75 & 100 & 95 & 100 & 75 & 100 & 100 & 53.43 & III & $\mathrm{Sn}$ & $\begin{array}{l}\text { Texture, } \\
\text { Salinity }\end{array}$ & $\begin{array}{c}\text { Irrigation management, } \\
\text { leaching, Tolerant } \\
\text { crops }\end{array}$ \\
\hline 37 & 75 & 100 & 95 & 100 & 80 & 100 & 100 & 57.00 & III & $\mathrm{Sn}$ & $\begin{array}{l}\text { Texture, } \\
\text { Salinity }\end{array}$ & $\begin{array}{c}\text { Irrigation management, } \\
\text { leaching, Tolerant } \\
\text { crops }\end{array}$ \\
\hline 38 & 30 & 100 & 95 & 90 & 85 & 100 & 100 & 21.80 & $\mathrm{~V}$ & Sn & Texture & Irrigation management \\
\hline 39 & 55 & 100 & 95 & 100 & 70 & 100 & 100 & 36.57 & IV & $\mathrm{Sn}$ & $\begin{array}{l}\text { Texture, } \\
\text { Salinity }\end{array}$ & $\begin{array}{c}\text { Irrigation management, } \\
\text { leaching, Tolerant } \\
\text { crops }\end{array}$ \\
\hline 40 & 75 & 100 & 95 & 100 & 65 & 100 & 100 & 46.31 & III & $\mathrm{Sn}$ & $\begin{array}{l}\text { Texture, } \\
\text { Salinity }\end{array}$ & $\begin{array}{c}\text { Irrigation management, } \\
\text { leaching, Tolerant } \\
\text { crops }\end{array}$ \\
\hline 41 & 55 & 100 & 95 & 100 & 75 & 100 & 100 & 39.18 & IV & $\mathrm{Sn}$ & $\begin{array}{l}\text { Texture, } \\
\text { Salinity }\end{array}$ & $\begin{array}{c}\text { Irrigation management, } \\
\text { leaching, Tolerant } \\
\text { crops }\end{array}$ \\
\hline 42 & 30 & 100 & 95 & 100 & 75 & 100 & 100 & 21.37 & $\mathrm{~V}$ & $\mathrm{Sn}$ & $\begin{array}{l}\text { Texture, } \\
\text { Salinity }\end{array}$ & $\begin{array}{c}\text { Irrigation management, } \\
\text { leaching, Tolerant } \\
\text { crops }\end{array}$ \\
\hline 43 & 30 & 100 & 95 & 100 & 80 & 100 & 100 & 22.80 & $\mathrm{~V}$ & $\mathrm{Sn}$ & $\begin{array}{l}\text { Texture, } \\
\text { Salinity }\end{array}$ & $\begin{array}{c}\text { Irrigation management, } \\
\text { leaching, Tolerant } \\
\text { crops }\end{array}$ \\
\hline 44 & 30 & 100 & 95 & 90 & 80 & 100 & 100 & 20.52 & $\mathrm{~V}$ & $\mathrm{Sn}$ & \begin{tabular}{l|} 
Texture, \\
Salinity
\end{tabular} & $\begin{array}{c}\text { Irrigation management, } \\
\text { leaching, Tolerant } \\
\text { crops }\end{array}$ \\
\hline 45 & 30 & 100 & 95 & 90 & 80 & 100 & 100 & 20.52 & $\mathrm{~V}$ & $\mathrm{Sn}$ & $\begin{array}{l}\text { Texture, } \\
\text { Salinity }\end{array}$ & $\begin{array}{c}\text { Irrigation management, } \\
\text { leaching, Tolerant } \\
\text { crops }\end{array}$ \\
\hline 46 & 30 & 100 & 95 & 100 & 70 & 100 & 100 & 19.95 & VI & $\mathrm{Sn}$ & $\begin{array}{l}\text { Texture, } \\
\text { Salinity }\end{array}$ & $\begin{array}{c}\text { Irrigation management, } \\
\text { leaching, Tolerant } \\
\text { crops }\end{array}$ \\
\hline
\end{tabular}

$(\mathbf{S}=\mathrm{A}, \mathrm{B}, \mathrm{C}, \mathrm{D}) \quad(\mathbf{n}=\mathrm{E}) \quad(\mathbf{W}=\mathrm{F}),(\mathrm{III}=$ Marginally suitable, 45-60\%), (IV= Almost unsuitable, 30-45\%), (V= Unsuitable, 20-30\% $)$ (VI= Completely unsuitable, $<20 \%$ ) 
Table 5. Land capability indexes for irrigation for the old cultivated location (second location), as calculated according to Sys and Verheye (1972). $\mathrm{Ci}=\mathrm{A} \times \mathrm{B} / \mathbf{1 0 0} \times \mathrm{C} / \mathbf{1 0 0} \times \mathrm{D} / \mathbf{1 0 0} \times \mathrm{E} / \mathbf{1 0 0} \times \mathrm{F} / \mathbf{1 0 0} \times \mathrm{G} / \mathbf{1 0 0}$

\begin{tabular}{|c|c|c|c|c|c|c|c|c|c|c|c|c|}
\hline $\begin{array}{c}\text { Profile } \\
\text { No. }\end{array}$ & $\begin{array}{c}\mathbf{A} \\
\text { Texture }\end{array}$ & $\begin{array}{c}\text { B } \\
\text { Depth }\end{array}$ & $\begin{array}{c}\mathbf{C} \\
\text { Carbonate }\end{array}$ & $\begin{array}{c}\text { D } \\
\text { Gypsum }\end{array}$ & $\begin{array}{c}\mathbf{E} \\
\text { Salinity }\end{array}$ & $\begin{array}{c}\mathbf{F} \\
\text { Drainage }\end{array}$ & $\begin{array}{c}\mathbf{G} \\
\text { Slope }\end{array}$ & $\begin{array}{c}\mathbf{C i} \\
\text { Capability } \\
\text { index }\end{array}$ & Class & $\begin{array}{c}\text { Sub } \\
\text { Class }\end{array}$ & $\begin{array}{c}\text { Major } \\
\text { problem }\end{array}$ & $\begin{array}{l}\text { Proposed manage- } \\
\text { ments }\end{array}$ \\
\hline 1 & 75 & 100 & 95 & 100 & 100 & 95 & 100 & 67.68 & II & Sw & Texture & $\begin{array}{l}\text { Irrigation manage- } \\
\text { ment }\end{array}$ \\
\hline 2 & 85 & 90 & 95 & 100 & 70 & 75 & 100 & 38.15 & IV & Snw & $\begin{array}{l}\text { Salinity, } \\
\text { Drainage }\end{array}$ & $\begin{array}{l}\text { leaching, Tolerant } \\
\text { crops, Improvement } \\
\text { of the drainage }\end{array}$ \\
\hline 3 & 75 & 90 & 95 & 100 & 85 & 95 & 100 & 51.78 & III & Snw & Texture & $\begin{array}{l}\text { Irrigation manage- } \\
\text { ment }\end{array}$ \\
\hline 4 & 55 & 90 & 95 & 90 & 100 & 95 & 100 & 40.2 & IV & Sw & Texture & $\begin{array}{l}\text { Irrigation manage- } \\
\text { ment }\end{array}$ \\
\hline 5 & 55 & 90 & 95 & 90 & 95 & 70 & 100 & 28.14 & V & Snw & $\begin{array}{c}\text { Texture, } \\
\text { Drainage }\end{array}$ & $\begin{array}{l}\text { Irrigation manage- } \\
\text { ment, Improvement } \\
\text { of the drainage }\end{array}$ \\
\hline 6 & 75 & 90 & 95 & 90 & 90 & 70 & 100 & 36.35 & IV & Snw & $\begin{array}{l}\text { Texture, } \\
\text { Drainage }\end{array}$ & $\begin{array}{l}\text { Irrigation manage- } \\
\text { ment, Improvement } \\
\text { of the drainage }\end{array}$ \\
\hline 7 & 55 & 100 & 95 & 100 & 75 & 70 & 100 & 27.43 & V & Snw & $\begin{array}{l}\text { Texture, } \\
\text { Salinity, } \\
\text { Drainage }\end{array}$ & $\begin{array}{l}\text { Irrigation manage- } \\
\text { ment, leaching, Tol- } \\
\text { erant crops, Im- } \\
\text { provement of the } \\
\text { drainage }\end{array}$ \\
\hline 8 & 55 & 90 & 95 & 90 & 80 & 70 & 100 & 23.7 & V & Snw & $\begin{array}{l}\text { Texture, } \\
\text { Salinity, } \\
\text { Drainage }\end{array}$ & $\begin{array}{l}\text { Irrigation manage- } \\
\text { ment, leaching, Tol- } \\
\text { erant crops, Im- } \\
\text { provement of the } \\
\text { drainage }\end{array}$ \\
\hline 9 & 55 & 90 & 95 & 90 & 80 & 70 & 100 & 23.7 & $\mathrm{~V}$ & Snw & $\begin{array}{l}\text { Texture, } \\
\text { Salinity, } \\
\text { Drainage }\end{array}$ & $\begin{array}{l}\text { Irrigation manage- } \\
\text { ment, leaching, Tol- } \\
\text { erant crops, Im- } \\
\text { provement of the } \\
\text { drainage }\end{array}$ \\
\hline 10 & 55 & 90 & 95 & 100 & 80 & 70 & 100 & 26.33 & $\mathrm{~V}$ & Snw & $\begin{array}{l}\text { Texture, } \\
\text { Salinity, } \\
\text { Drainage }\end{array}$ & $\begin{array}{l}\text { Irrigation manage- } \\
\text { ment, leaching, Tol- } \\
\text { erant crops, Im- } \\
\text { provement of the } \\
\text { drainage }\end{array}$ \\
\hline 11 & 55 & 90 & 95 & 100 & 80 & 70 & 100 & 26.33 & V & Snw & $\begin{array}{l}\text { Texture, } \\
\text { Salinity, } \\
\text { Drainage }\end{array}$ & $\begin{array}{l}\text { Irrigation manage- } \\
\text { ment, leaching, Tol- } \\
\text { erant crops, Im- } \\
\text { provement of the } \\
\text { drainage }\end{array}$ \\
\hline 12 & 75 & 100 & 95 & 90 & 80 & 100 & 100 & 51.3 & III & $\mathrm{Sn}$ & $\begin{array}{l}\text { Texture, } \\
\text { Salinity }\end{array}$ & $\begin{array}{l}\text { Irrigation manage- } \\
\text { ment, leaching, Tol- } \\
\text { erant crops }\end{array}$ \\
\hline 13 & 95 & 100 & 95 & 100 & 80 & 75 & 100 & 54.15 & III & Snw & $\begin{array}{l}\text { Salinity, } \\
\text { Drainage }\end{array}$ & $\begin{array}{l}\text { leaching, Tolerant } \\
\text { crops, Improvement } \\
\text { of the drainage }\end{array}$ \\
\hline 14 & 75 & 100 & 95 & 100 & 80 & 95 & 100 & 51.15 & III & Snw & $\begin{array}{l}\text { Texture, } \\
\text { Salinity }\end{array}$ & $\begin{array}{l}\text { Irrigation manage- } \\
\text { ment, leaching, Tol- } \\
\text { erant crops }\end{array}$ \\
\hline 15 & 75 & 100 & 95 & 90 & 100 & 95 & 100 & 60.91 & II & Sw & Texture & $\begin{array}{c}\text { Irrigation manage- } \\
\text { ment }\end{array}$ \\
\hline 16 & 55 & 100 & 95 & 100 & 70 & 95 & 100 & 34.74 & IV & Snw & $\begin{array}{l}\text { Texture, } \\
\text { Salinity }\end{array}$ & $\begin{array}{l}\text { Irrigation manage- } \\
\text { ment, leaching, Tol- } \\
\text { erant crops }\end{array}$ \\
\hline 17 & 100 & 100 & 95 & 90 & 70 & 75 & 100 & 44.88 & IV & Snw & $\begin{array}{l}\text { Salinity, } \\
\text { Drainage }\end{array}$ & $\begin{array}{l}\text { leaching, Tolerant } \\
\text { crops, Improvement } \\
\text { of the drainage }\end{array}$ \\
\hline 18 & 90 & 100 & 95 & 100 & 75 & 75 & 100 & 48.09 & III & Snw & $\begin{array}{l}\text { Salinity, } \\
\text { Drainage }\end{array}$ & $\begin{array}{l}\text { leaching, Tolerant } \\
\text { crops, Improvement } \\
\text { of the drainage }\end{array}$ \\
\hline
\end{tabular}

$(\mathbf{S}=\mathrm{A}, \mathrm{B}, \mathrm{C}, \mathrm{D})(\mathbf{n}=\mathrm{E})(\mathrm{W}=\mathrm{F}),(\mathrm{II}=$ Moderately suitable, 60-80\%), (III= Marginally suitable, 45-60 \% $)$, $(\mathrm{IV}=$ Almost unsuitable, 30-45 \%), (V= Unsuitable, $20-30 \%)$ 


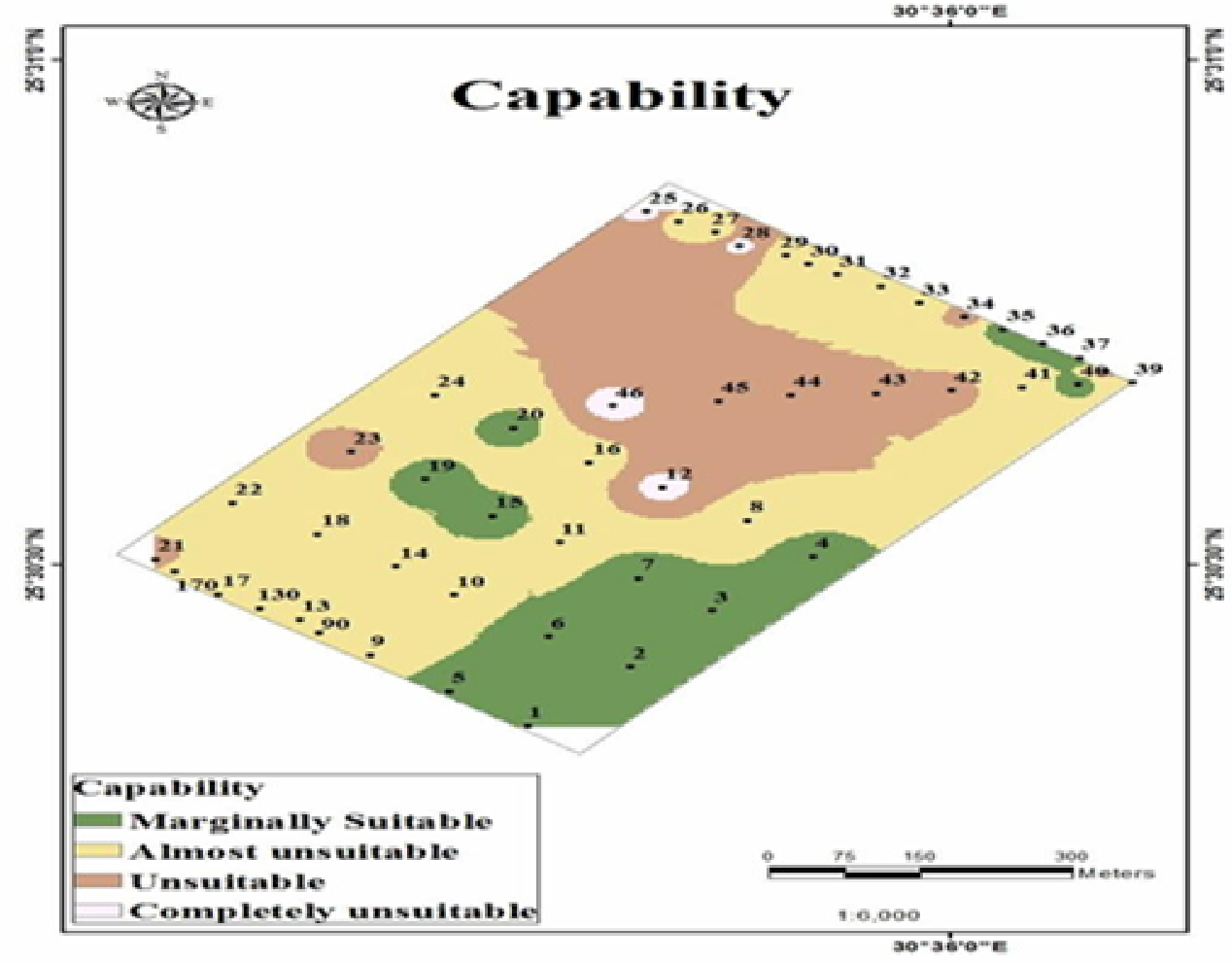

(a) New uncultivated location

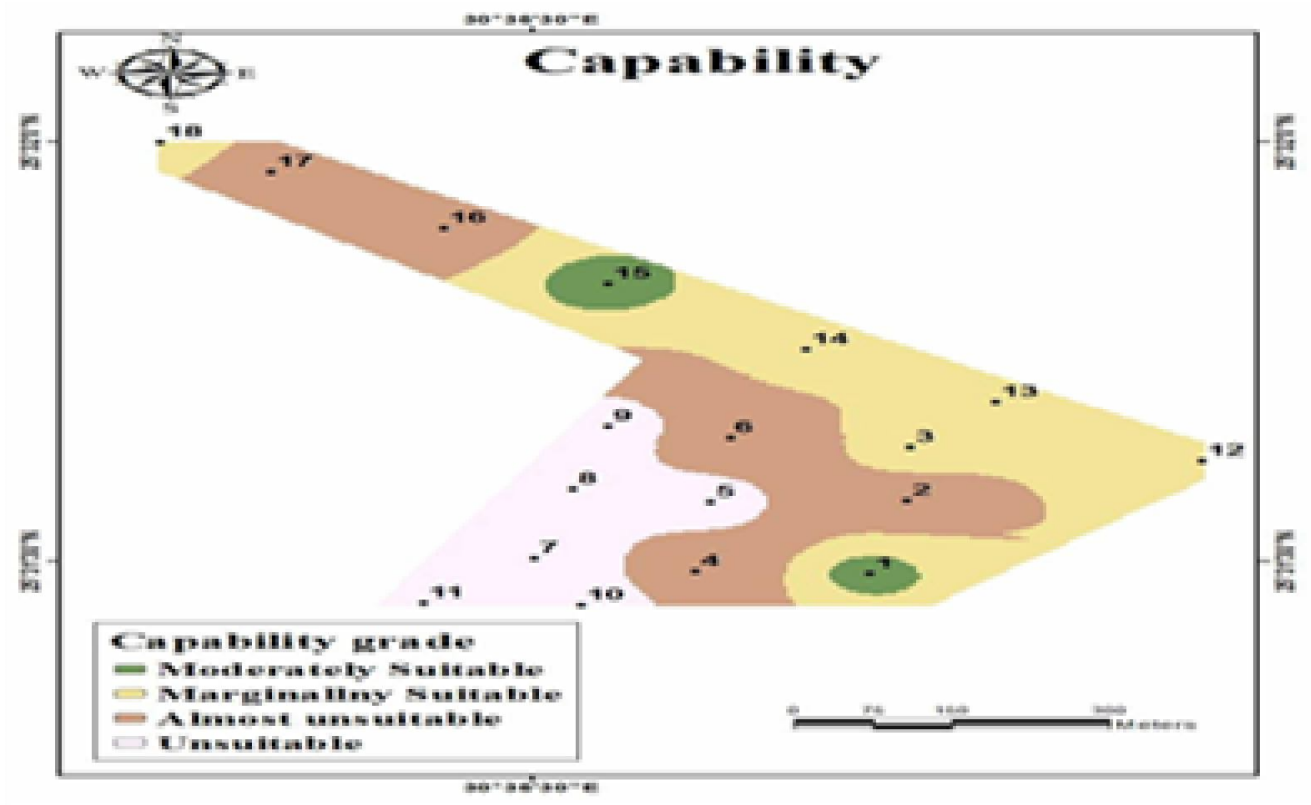

(b) Old cultivated location

Fig.6: The distribution of capability indexes for irrigation as calculated according to Sys and Verheye (1972), for both locations. 


\section{Recommendations}

The land capability can be improved by applying, these soil management practices;

- Improving drainage.

- Leaching salt using modified surface irrigation, cultivate salt tolerant crops.

- No deep plowing because salts are in subsurface.

- Improve soil permeability some time applying sand to the soil may help.

- Organic fertilization to improve permeability, CEC and nutrient availability.

- Applying modern irrigation systems.

- Reducing the irrigation periods to avoid the soil surface salt crust formation.

- Application of non-saline dredged clay or sand materials to improve the physical properties of the sandy soils or to increase permeability of heavy clay soils.

- Improved the soil fertility by precise fertilization managements.

\section{References}

Abd - Allah, H. 2002. Use of field morphological rating system to evaluate the soils development of Elkharga Oasis. Mansoura J. Agric. Sci., 27(11):7963-7977.

Baver, L.D. 1963. "Soil physics" John Wiley \&Inc., New York. USA.

Blake G. R. and K. H. Hartge. 1986. Particle density. P. 377-382. In A. Klute (ed.) "Methods of Soil Analysis" part 1. Physical and Mineralogical Methods. Agron. Monogr. 9. $2^{\text {nd }}$ ed. ASA and SSSA. Madison. WI.

Bodman, A.G. 1946. Memiographed laboratory notes on soil character- istics. University of California, U.S.A.

El-Barkouky, A.N. 1979. Preliminary investigations of ground water and soil resources in East Oweynat area Western Desert. Egypt G.P.C. Rept.

El-Hamdi, A.R., 1990. "Pedochemical studies on soils of some depressions in the Western Desert". Ph. D., Thesis, Fac. Agric., Moshtohor, Zagazig, Univ., Egypt.

Ghoubachi, S.Y., and A.M. Baraka. 2006. Geological settings and their bearing upon the occurrences of shallow water bearing horizon in North El-Kharga depression, Western Desert, Egypt. Desert Research Center.

Hammad, M.A. and M.A. Hussein. 1993. Clay mineralogy of some soil profiles in relation to their parent materials and landforms in Elkharga oasis, Egypt. Al-Azhar J. Agric. Res., 18: 323-338.

Harga, A.A. 1977. Soils of Kharga and Dakhla Oases: I. Granulometric analysis and soil uniformity. Desert Inst. Bull., A.R.E., 26 (2): 469-488.

Harga, A.A. 1979. Soils of Kharga and Dakhla Oases: I. Geomorphology and classification of some representative profiles. Desert Inst. Bull., A.R.E., 72(2): 85-97.

Jackson, M.L. 1967. Soil Chemical Analysis. Prentice-Hall., Inc., Englewood Cliffs, New Jersey, USA.

Jackson, M.L. 1969. Soil Chemical analysis-advanced course. Published by author, Soil Sci. Dept., Wisconsin Uni., Madison, USA.

Jackson, M.L. 1973. Soil Chemical analysis. Prentice-Hall of India private Limited New Delhi.

Nelson, R.E. 1982. Carbonate and gypsum. Cited from USDA (1991). Soil Survey Laboratory Methods 
Manual. Soil Survey Investigations Report No.42 Version 1:280-284.

Olsen, S.R., C.V. Cole, F. Watanabe and L. A. Dean. 1954. Estimation of available phosphorus in soil by extraction with sodium bicarbonate. Cric. 989, USDA, Washington, D.C.

Richards, L.A. 1954. Diagnosis and Improvement of Saline and Alkaline Soils. United States Dept. of Agric., Handbook No. 60.

Salama, S.B. 1965. Mineralogical and chemical Studies of the clay fraction of the soils of kharga Oasis in comparison to the alluvial soils of Egypt. M.Sc. Thesis, Fac. Agric., Cairo Univ. Egypt.

Selmy, S.A.H. 2005. Studies on Some Shale -Derived Soils in the New
Valley, Egypt. M.Sc. Thesis, Fac. Agric., Assiut Univ., Assiut, Egypt.

Soil Survey Staff. 1999. Soil Taxonomy. Soil Conservation Service, U.S. Dept. of Agric., Washington, D.C.U.S.A. Seventh edition. USA.

Soil Survey Staff 1951. Soil Survey manual. U.S. Dept. of Agric., Handbook, No.18. Government printing Office, Washington, D.C. U.S.A.

Sys, C. and W. Verheye, 1972. Principles of land classification in arid and semi-arid regions. International Training Centre for Post-Graduate Soil Scientists, State University of Ghent, Belgium. 
تأثير الزراعة علي خواص التربة بمزرعة الخارجة، بالو ادي الجديد

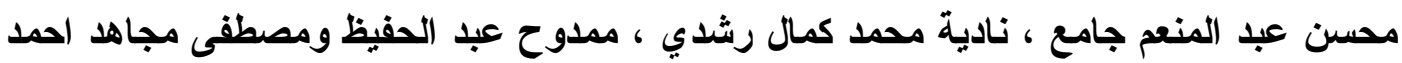

قسم الار اضى و المياه كلية الزر اعة جامعة اسيوط

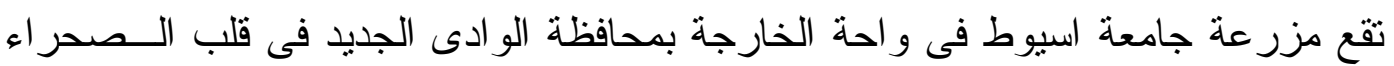

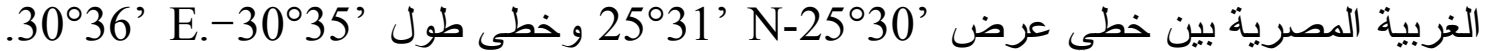

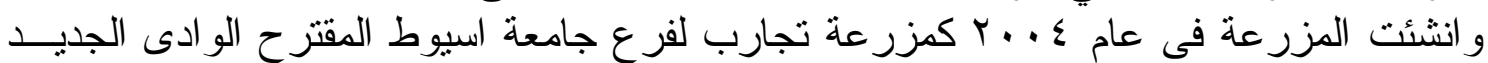

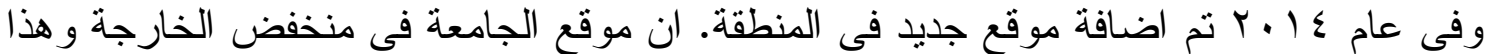

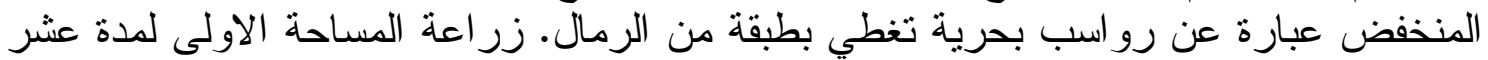

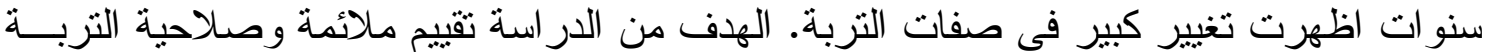

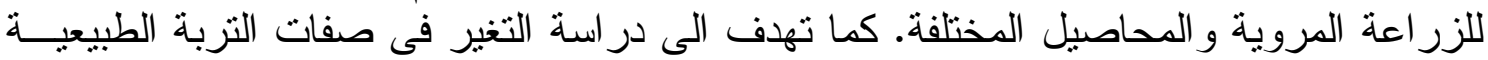

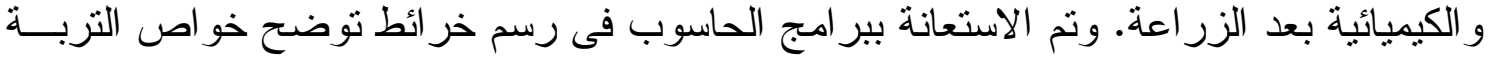

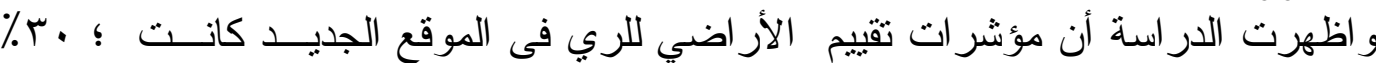
وملائمتها للزر اعة.

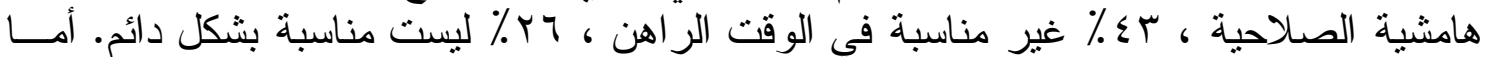

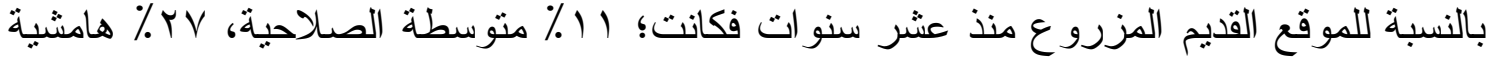

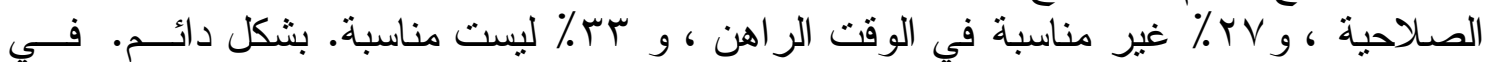

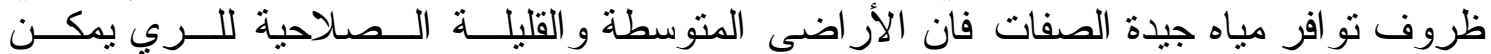

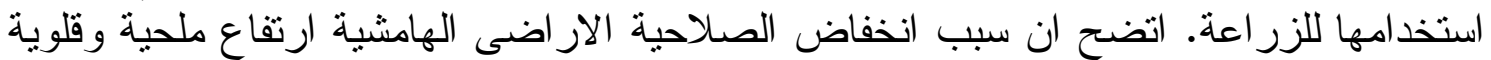

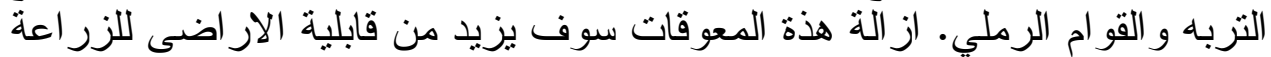

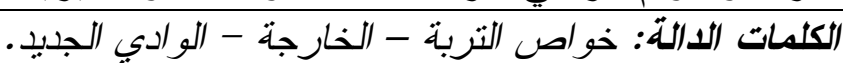

